\title{
O migrante nordestino e a cena gastronômica do Bairro do Bixiga (São Paulo/SP)
}

\section{The Northeastern migrant and the gastronomic scene of Bixiga neighborhood (São Paulo)}

\section{Anna Paula Telino de Abreu Fernandes ${ }^{1}$}

A cidade de São Paulo (SP) há muitos anos atrai migrantes, que a consideram um lugar com capacidade de prover melhores oportunidades. Dos grupos que migraram para São Paulo, os nordestinos merecem uma atenção à parte, tanto por representarem parcela expressiva nessa população quanto pela contribuição inegável para o desenvolvimento da cidade. Motivados por fatores diversos, os nordestinos tinham algo em comum: a busca por trabalho e em consequência a melhoria das suas condições de vida. A partir da década de 1970 um bairro em particular tornou-se destino atrativo para eles, em virtude da presença de edificações com baixo custo de aluguel e a sua proximidade com o centro da cidade: o Bixiga. Ocupado inicialmente por ex-escravos, o bairro recebeu significativo contingente de imigrantes, sobretudo os italianos, que acabaram se tornando "símbolo" de representação do bairro. Esse foco na temática italiana, contudo, acaba ofuscando as demais comunidades que coexistem no bairro cuja combinação sociocultural o torna um local multiétnico, rico em diversidade, onde o contato com a alteridade é frequente. Esse trato com a alteridade impacta diretamente a formação dos processos identitários desses migrantes, que a partir das relações interculturais passam a encarar suas identidades como múltiplas; a comida, representante das culturas e sociedades, porta-se como elemento essencial nesse processo. Encontra-se associada ao processo de afirmação de identidades e adaptação dos migrantes à cidade. Também é tida como um meio de reconectar o migrante à sua origem, preservando raízes mesmo estando longe, criando um "senso de casa" onde quer que tenha ido morar. Os migrantes nordestinos possuem forte laço com a comida, e frequentemente ela se torna labor; eles são identificados como atores importantes na cena gastronômica de São Paulo. No Bixiga, hoje representam proprietários de empreendimentos do ramo gastronômico, chefs, cozinheiros, brigada de salão, dentre outras funções. Os migrantes nordestinos são considerados mão de obra versátil, tidos como bons observadores, sendo hábeis em se relacionar com diferentes cozinhas étnicas, rapidamente se familiarizando com elas e não se limitando apenas à sua cozinha típica, sendo assim imprescindíveis para a manutenção do status do Bixiga de polo gastronômico da cidade. Assim, o objetivo geral proposto nesse trabalho é discutir o papel do migrante nordestino na cena gastronômica do Bixiga. Para tanto foi adotada a etnografia, cujas técnicas de coleta foram a observação participante, entrevistas abertas semiestruturadas gravadas e transcritas, com a finalidade de registrar as experiências vividas pelos indivíduos. Como resultado, foi observado que apesar de merecerem reconhecimento, os empreendimentos nordestinos possuem baixa expressividade na cena gastronômica do bairro e a presença nordestina nas cantinas como mão de obra, apesar de imprescindível, é apagada.

Palavras-chave: nordestinos; identidade; comida nordestina; Bixiga.

Keywords: Northeastern migrants; identity; Northeastern food; Bixiga. 